\title{
A fenntartható információs társadalom ideológiai tájképe
}

A tanulmány a fenntartható információs társadalom eszméjének elméleti és ideológiai aspektusait tárgyalja, mérlegre téve Robin Mansell, Lorenz Hilty és Franz Josef Radermacher ezzel kapcsolatban megfogalmazott gondolatainak ideológiai implikációit. A mai társadalom ökológiai, gazdasági-társadalmi, politikai és kulturális alrendszereinek fenntartható vagy nem fenntartható fejlődésére, illetve a fenntarthatóság mértékére vonatkozóan rendelkezésre álló adatok elemzése alapján megpróbálja kimutatni, hogy a fenntarthatóság, a felelősség, a részvétel és a befogadás vagy az együttműködés eszméi - az információs társadalom fogalmával kombinálva - gyakran ideológiai köntösbe bújtatva jelennek meg. A szerző következtetése szerint az olyan célképzetek körvonalazásakor, mint például a fenntartható információs társadalom, óvatosan kell eljárni.

Kulcsszavak: fenntartható információs társadalom, fenntarthatóság, társadalomelméletek, etika, ideológia, ideológia-kritika

\section{Szerzői információ:}

Christian Fuchs

Informatikus és társadalomteoretikus, az információs és kommunikációs technológiák társadalmi hatásaival foglalkozó posztgraduális oktatási és kutatási központ (ICT\&S Center: Advanced Studies and Research in Information and Communication Technologies \& Society) docense a Salzburgi Egyetemen. Az Internet és társadalom: társadalomelmélet az információ korában (Internet and Society: Social Theory in the Information Age) címú könyve 2008-ban jelent meg a Routledge Kiadónál. Kutatási területei: társadalomelmélet, kritikaelmélet, a média politikai gazdaságtana, kommunikáció, az információs társadalom elmélete. (http://fuchs.icts.sbg.ac.at)

Így hivatkozzon erre a cikkre:

Fuchs, Christian. „A fenntartható információs társadalom ideológiai tájképe.”

Információs Társadalom IX, 2. szám (2009): 7-19.

$\Longrightarrow$ https://dx.doi.org/10.22503/inftars.IX.2009.2.1


Christian Fuchs

\section{A fenntartható információs társadalom \\ ideológiai tájképe 1 . rész ${ }^{1}$}

\section{Bevezetés}

E tanulmány a fenntartható információs társadalom eszméjével foglalkozik. Az utóbbi húsz év tudományos és közéleti vitáiban kiemelkedó szerephez jutott a fenntarthatóság fogalma. Az egyesek által kockázattársadalomnak nevezett mai világban (Beck 1992), ahol az emberiség egzisztenciális kockázatokkal néz szembe, fontossá válnak a túlélés kérdései: a fenntarthatóság növekvố jelentôsége elsôsorban ebben az összefüggésben magyarázható.

A fogalom leginkább elfogadott meghatározását a Környezet és Fejlődés Világbizottsága (World Commission on Environment and Development, WCED) adta meg. Eszerint a fenntartható fejlődés ,anélkül biztosítja a jelen szükségleteit, hogy veszélyeztetné a jövóbeli generációk lehetőségeit saját majdani szükségleteik kielégítésére" (WCED 1987: 43). Ezt a definíciót kezdetben úgy értelmezték, hogy mindenekelótt az ökológiai problémák megoldásának szükségességére helyezi a hangsúlyt. Az ENSZ-nek a környezet és a fejlődés témájában 1992-ben rendezett Rio de Janeiró-i konferenciája (az ún. „Föld-csúcstalálkozó”) fontos mérföldkövet jelentett a fenntarthatósággal kapcsolatos diskurzus kibontakozásában, majd a fenntartható fejlődésról 2002-ben Johannesburgban tartott világ-csúcstalálkozó is ráirányította a közvélemény figyelmét erre a kérdésre. A fenntarthatóság fogalmának általánosan elfogadott értelmezési tartománya kitágult, és ma nem korlátozódik az ökológiára, hanem kiterjed a gazdasági, a társadalmi és az intézményi dimenziókra is (vö. Serageldin 1995).

A fenntartható fejlődés gondolatának valamiféle megelólegezése fellelhetố Karl Marx írásaiban. Marx azt állítja, hogy egy szabad társadalomban az emberi lényeknek gazdagítaniuk kell bolygónkat, és egyre jobb állapotban kell továbbadniuk azt a következő generációknak. „Egy magasabb gazdasági társadalomalakulat álláspontjáról az, hogy a földgolyó egyes egyének magántulajdonában van, éppoly képtelenségnek fog látszani, mint az, hogy az egyik ember a másik magántulajdonában van. Még egy egész társadalom, egy nemzet, sốt az egy idóben létező összes társadalmak együttvéve sem tulajdonosai a földnek. Csak birtokosai, haszonélvezói annak, és mint boni patres familias [jó családapák], kötelesek jobb állapotban hagyni örökül a következố nemzedékeknek" (MEW 25: 784). ${ }^{2}$ Ez a definíció nagyon hasonló a Környezet és Fejlődés Világbizottsága (WCED) által megadotthoz. Marx is azt állítja, hogy az egyes generációknak jobbítaniuk kell a társadalmat és a környezetet. Marx és a WCED álláspontja

\footnotetext{
' A tanulmányt - a szerzó hozzájárulásával - terjedelmi okokból kissé rövidítve, két részletben közöljük. A swerk.

${ }^{2}$ Az idézet forrása magyarul: A tóke. III. kötet (1864-1865); http://www.marx.extra.hu/MT3.pdf. Letöltve: 2009. február 19-én. Eredeti megjelenés: MEM 25. 731. Budapest, 1951, Szikra Könyvkiadó. - A ford.
} 
között az a különbség, hogy Marx a termelési eszközök magántulajdonát a fenntartható társadalom megteremtését gátoló anyagi akadálynak tekintette.

E tanulmány célja kritikai vizsgálat tárgyává tenni az információs társadalom és a fenntarthatóság eszméjének összekapcsolódását. Mit nevezünk fenntartható információs társadalomnak? Van értelme ennek a fogalomnak? Van valóságos politikai potenciálja, vagy csupán olyan ideológia, amely könnyú látszatmegoldásokat ígér komplex problémákra? Az információs és kommunikációs technológiák (IKT) és a tudás valóban lehetőséget adnak a társadalom globális problémáinak megoldására?

Megvizsgáljuk, hogy ideológiai jellegú-e a fenntartható információs társadalom fogalma, és hordoz-e magában pozitív lehetôségeket. Ennek eldöntéséhez a második részben bemutatjuk az ideológiakritika alapjait. Annak a kérdésnek a mérlegeléséhez, hogy a fenntartható információs társadalom eszméje vajon ideológiának tekinthető-e, mindenekelốtt tudnunk kell, mi az ideológia, és az ideológiák hogyan múködnek. A társadalom jelenlegi állapotának, valamint a fenntarthatóság eléréséhez meglévő lehetőségek áttekintéséhez a harmadik részben bizonyos statisztikai adatokat elemzünk. Mindezek alapján a negyedik részben a fenntartható információs társadalom három vezetố tudós (Robin Mansell, Lorenz Hilty, Franz Josef Radermacher) nevéhez fúzốdó meghatározásait tárgyaljuk. A mai társadalom jellemzóire vonatkozó statisztikai adatok és az ideológiai vonások elemzése alapján megvizsgáljuk, hogy ezek az értelmezések mennyiben ideológiai jellegúek. Végül az ötödik részben az elmondottakból levonható következtetéseket mutatjuk be.

\section{Az ideológiakritika alapjai}

Az ideológia és az ideológiakritika fogalmát a marxista gondolkodók tárgyalják a legtüzetesebben. Az ideológia fogalma már Marx munkáiban is igen fontos szerephez jutott, majd az ốt követô marxista tudósok azt részletesebben is kidolgozták. A marxi ideológiafogalom realista ontoepisztemológiai alapokon nyugszik, vagyis abból a feltételezésból indul ki, hogy a valóság objektíve létezik, és a tudósok képesek leírni és elemezni a társadalmat úgy, ahogy van. A társadalomnak a tényleges állapotában, illetve valamilyen elképzelt vagy kívánatos formájában való megragadása képezi az alapot az olyan eltorzított világnézetek, elméletek és tanok megítéléséhez, amelyek szerint a valóság a ténylegesen fennálló vagy potenciálisan elérhetố állapotától eltérố módon szerveződik, illetve szervezhetô. Az ideológiakritika a valóság efféle reprezentációit elnyomó érdekek szolgálatában állónak tekinti.

Engels szerint az eszmék „a valóság - hú vagy elferdített - visszatükrözódései” (MEW 20: 573). Ha az eszmék torz képet adnak a világról, ez annyit jelent, hogy az objektív valóság az emberek tudatában hamis, nem identikus formákban reprezentálódik. Marx - az ideológiát camera obscurához hasonlítva - rámutat, hogy az ideológiák tévesen reprezentálják a valóságot, mivel az eszméket tekintik elsôdlegesnek, és így a feje tetejére állítják a világot. „Ha az emberek és viszonyaik az egész ideológiában, mint valami camera obscurában, fejük tetejére állítva jelennek meg, ez a jelenség épp 
úgy történelmi életfolyamatukból ered, mint ahogy a recehártyán a tárgyak megfordítása közvetlen fizikai életfolyamatukból”3 (MEW 3: 26).

Marx azt fejtegette, hogy az ideológia az uralkodó osztály érdekeinek kifejezốdése, és egyben az elnyomottak ellenốrzését szolgálja. [...] Szerinte ,az erkölcs, a vallás, a metafizika és minden más ideológia” nem egyebek, mint „az emberi elmében képződött fantomok" (MEW 3: 26f). Marx a vallást már a hegeli jogfilozófia kritikájának jól ismert bevezetésében is olyan ideológiának tekintette, ami „a népek ópiumaként” múködik, és ahhoz vezet, hogy ,a világ megfordítva képezódik le a tudatban” (MEW 1: 378).

Azt a felismerést, hogy az ideológia eltorzítja a valóságot, késóbb részletesebben is kifejtette $A$ tóke első kötetének az árufetisizmussal foglalkozó fejezetében (MEW 23: 85-98). [...] Álláspontja szerint a javak áru jellege elfedi, hogy ezek a javak csakis azért léteznek, mert emberi munkával, osztályviszonyok között létrehozták óket. Ily módon jön létre az a „csalóka képzet”, hogy az áru, a tóke és a pénz természetes módon létező dolgok, és nem vezethetốk vissza társadalmi alapokra. Itt Marx ismét „a vallási világ ködbe burkolózó régióira" utal (MEW 23: 86), és a vallással kapcsolatos eredeti kritikáját kiterjeszti a kapitalizmusra, hogy rámutathasson: az áruk és a tốke létezố formáiban a valóság manipulációja és eltorzítása jelenik meg. Az áruk fétis jellege érvényesül a kapitalista tömegközlési eszközökben is: a kapitalizmus elnyomó rendszerét a média szentesíti, és megváltoztathatatlanként mutatja be, elkendőzve, hogy az történelmileg alakult ki, társadalmi küzdelmek útján megváltoztatható, és végeredményben a társadalmi fejlódés és a társadalmi viszonyok terméke.

Lukács György magyar filozófus (1923/1972) szerint a burzsoá ideológia - történelmietlen módon - megkísérli a kapitalizmus létezését megváltoztathatatlan törvényként feltüntetni. [...] Az ideológia immanensen jelen van magának a kapitalizmusnak a gazdasági formáiban is. [...]

Antonio Gramsci olasz marxista teoretikus azzal a meglátással egészítette ki Marx ideológiaelméletét, hogy az ideológiát nem egyszerúen a domináns csoportok kényszerítik rá az alávetettekre, hanem az utóbbiak el is fogadják alávetett helyzetüket azzal, hogy nem hajlamosak ellenállást tanúsítani - vagy abban a reményben, hogy a hatalom támogatásával elő́nyökhöz jutnak, vagy pedig azért, mert nem látnak keresztül a számukra tálalt hazugságokon, és ennek következtében beleegyezésüket adják saját elnyomásukhoz (Gramsci 1971: 266). [...] Louis Althusser (1971/1994) szerint az ideológiákban valójában az osztályviszonyok, továbbá olyan hitek és meggyoózódések, illetve olyan gondolkodási, cselekvési és elnyomási módok jutnak kifejezésre, amelyekben a valóság nem úgy jelenik meg, ahogyan ténylegesen létezik. [...] Az ideológiák azoknak a domináns csoportoknak az eszméit és érdekeit fejezik ki, amelyek a valóságot egy bizonyos módon kívánják beállítani, és a nekik alávetett csoportokat - annak érdekében, hogy azok ne fejtsenek ki ellenállást a hatalommal szemben, és fogadják el saját elnyomott helyzetüket - megpróbálják meggyốzni, hogy a valóságot ugyanúgy lássák. Az, aki egy bizonyos ideológia hívéül szegốdik, bizonyos gyakorlatokat követ (templomba jár, találkozókon vesz részt, az információ és a kultúra fogyasztójaként viselkedik stb.).

\footnotetext{
${ }^{3}$ Az idézet forrása magyarul: Marxista Elektronikus Könyvtár, http://www.marx.extra.hu, Marx és Engels válogatott múvei. I. kötet. A német ideológia. Eredeti megjelenés: Budapest, 1952, Szikra Könyvkiadó. - A ford.
} 
pán eszmék, hanem anyagilag is léteznek. Az, hogy az ideológia az emberi lényeket valamely felsóbb hatalom nevében, alárendeltekként szólítja meg (Althusser kifejezésével: az „interpelláció”), annyit jelent, hogy az ideológia megpróbálja meggyőzni vagy kényszeríteni az egyént, hogy higgyen egy bizonyos erô (Isten, vezetô, állam, fônök, guru, pénz, piac stb.) felsóbbségében, és saját cselekedeteit és gondolkodását vesse alá egy ilyen „abszolút alany” akaratának.

A frankfurti iskola érvelése szerint a 20. századi kapitalizmus kialakulásával a kultúra termékei és a tömegközlési eszközök olyan árucikkekké váltak, amelyek leegyszerúsítik és eltorzítják a valóságot, és az embereket azáltal tartják féken, hogy könnyú szórakozással bódítják el óket. Ily módon a tudat is olyan eszközzé válik, mint a gép: a reflexiót automatikus reakciókkal helyettesítik, és szabványosítják a gondolkodást, éppen annak érdekében, hogy a fennálló társadalmi berendezkedés lehetséges alternatíváira többé ne is gondoljon senki, s így azok megvalósulása valószínútlenné váljon. „A kulturális ipar minden egyes manifesztációja óhatatlanul olyan egyedekként reprodukálja az emberi lényeket, amilyenné az egész rendszer tette óket" (HorkheimerAdorno 1944/2002: 100). [...] Herbert Marcuse ebben az összefüggésben arról beszélt, hogy az egydimenziós társadalom eredményeként egydimenziós tudat alakul ki: „A fejlett ipari kultúra bizonyos értelemben még ideologikusabb, mint az elődje, amennyiben ma az ideológia benne foglaltatik magában a termelési folyamatban [...]” (Marcuse 1964: 11f).

A marxista ideológiaelméletról sok mindent mondhatnánk még (vö. Žižek 1994), de erre nincs itt módunk, ezért a tárgyalást néhány fontosabb gondolkodóra kell korlátoznunk. Az ideológia olyan eszköz, melynek felhasználásával a domináns csoportok a fennálló viszonyok igazolására és a változások gátolására szolgáló világszemléleti eszmerendszert terjesztenek az általuk irányított csoportok és egyének körében, akikkel szemben igyekeznek fenntartani elójogaikat, és akiknek a kárára ellenőrzésük alatt kívánják tartani az erőforrásokat. Az elnyomottak erre vagy úgy válaszolnak, hogy részben vagy egészében reprodukálják az ideológiát, vagy pedig úgy, hogy azt figyelmen kívül hagyva más értelmezéseket és eszméket dolgoznak ki, amelyek irányt mutatnak az ellenálláshoz. Az elnyomottak részéról mindkét esetben gyakorlati, anyagi formában érkezik válasz. Az, hogy a válaszként kialakuló gyakorlat milyen lesz, nincs elöre meghatározva, de kondicionált. Valószínúbb, hogy inkább az egyeduralmat szolgáló, mintsem hegemóniaellenes gyakorlatok fognak kialakulni, mivel a domináns csoportok és egyének olyan, folyamatosan múködő struktúrákat (oktatás, propaganda, tömegközlési eszközök, vallás, egyesületek stb.) használnak fel a saját céljaik érdekében, amelyek segítségével biztosítani igyekeznek a pozitív válaszokat. Az ideológiákra nehezebb nemet mondani, mint igenló választ adni. A sikeres ideológiák hamis tudatot, vagyis olyan gondolatvilágot produkálnak és reprodukálnak, amely más lehetőségekkel szemben az adott feltételek elfogadását sugallja. Az ,igaz tudat” ezzel szemben olyan állapotok megteremtésére törekszik, amelyek mindenkinek hasznára vannak. Ilyen állapot írható le a részvételi demokrácia feltételeivel (Macpherson 1973).

Az ideológiák a következố módszerekkel élhetnek:

A problémák leszúkitése egyes hátrányos helyzetü csoportokra és személyekre vagy egyes társadalmi alrendszerekre. Ebben az esetben a problémák okozóiként a társadalom egyes alrendszereit vagy bizonyos hátrányos helyzetú csoportjait tüntetik fel, amelyek maguk 
is a rendszer áldozatai, s ebból az a következtetés adódik, hogy ezeket ki kell iktatni. A valódi okok megváltoztatásának akadályozása céljából a problémákat ilyenkor bizonyos személyekre vagy más partikuláris entitásokra redukálják. Erre példa a rasszizmus logikája, amely bizonyos jelenségek más jelenségekkel és rendszerekkel való kölcsönös összefüggéseit, valamint a bonyolultabb összefüggéseket nem veszi tudomásul.

A redukcionista fetisizmus túlhangsúlyozza bizonyos dolgok szerepét a problémák megoldásában, nem fordítva figyelmet a problémákat létrehozó és reprodukáló mélyebb társadalmi viszonyokra. A problémák megoldása a dolgokra redukálódik. Ezt látjuk például a technológiai determinizmus esetében, amely a technológiától várja a problémák megoldását, vagy a konzumerizmus ideológiájában, ahol a fogyasztás eszméje és az áruk birtoklásának ígérete jelenik meg felszabadítóként és a boldogság forrásaként.

A holisstikus automatizmus hívei a meglévő rendszer törésmentes belső fejlődésébe vetett hit megalapozására törekedve igyekeznek elodázni a problémák kezelését. Feltételezik, hogy nem fordulhatnak eló múködési zavarok, a rendszer mindig képes megoldani saját problémáit, csak várni kell, és nem kell tenni semmit. Erre példa a neoliberalizmus logikája, amely azon a meggyôződésen alapul, hogy a gazdaság és a társadalom valamennyi aspektusának megszervezésére a piac a legjobb eszköz.

A lehetséges alternatíuák dualisztikus elvetése vagy tagadása a meglévố társadalmat a lehető legjobb társadalomként tünteti fel. A dualista felfogás jegyében a jövő lehetséges alternatívái - mint elképzelhetetlenek vagy megvalósíthatatlanok - leválasztódnak a jelenról: bizonyos fejlemények bekövetkezése valószínútlennek minôsül, vagy egyszerüen figyelmen kívül marad.

A dualista pluralizmus különféle célok egyidejúleg való kitűzését jelenti, annak figyelembevétele nélkül, hogy ezek összeütközésbe kerülhetnek egymással. Erre a felfogásra a többszörös oksági kapcsolatok egymástól független érvényesülésének feltételezése jellemzó.

A különféle ideológiákban a fenti elemek bármilyen kombinációja előfordulhat.

\section{Az információs társadalom helyzete}

\subsection{Az ökológiai rendszer állapota}

1989 és 1993 között 28 fejlett ország ${ }^{4}$ teljes lakosságának 59,4\%-a ( $\mathrm{N}=37$ 182) egyetértett vagy erốsen egyetértett azzal, hogy a kormányoknak csökkenteniük kellene a környezet szennyezését (World Values Survey). Ez az arány 1999 és 2004 között $66,9 \%$-ra emelkedett $(\mathrm{N}=32$ 613).

1990-ben a világ összesített elsődleges energiaellátásának 81,2\%-a fosszilis tüzelőanyagokon alapult (25,3\% szén, 36,8\% olaj, 19,1\% földgáz). Ez az arány a 81,0\%-os szinten majdnem állandó maradt 2005-ben is (25,3\% szén, 35,0\% olaj, 20,7\% földgáz).

\footnotetext{
${ }^{4}$ Ausztria, Belgium, Bulgária, Kanada, Cseh Köztársaság, Dánia, Észtország, Finnország, Franciaország, Németország (Kelet- és Nyugat-Németország együtt), Nagy-Britannia, Magyarország, Izland, Írország, Olaszország, Japán, Lettország, Litvánia, Málta, Hollandia, Lengyelország, Portugália, Románia, Szlovákia, Szlovénia, Spanyolország, Svédország, Egyesült Államok.
} 
és hulladék) a teljes energiaellátásnak 1990-ben a 12,8\%-át, 2005-ben pedig a 12,6\%-át tették ki, míg a nukleáris energia részesedése 1990-ben 6,0\%, 2005-ben pedig 6,3\% volt (az adatok forrása: UN Human Development Report 2007/2008, 23. táblázat).

A világ teljes évi szén-dioxid-kibocsátása az 1990. évi 22 702,5 millió tonnáról 2004-ig 28 982,7 millió tonnára emelkedett. A legnagyobb kibocsátók a magas jövedelmú országok voltak. 2004-ben ezek bocsátották ki a légkörbe jutó teljes szén-dioxidmennyiség 44,8\%-át. A közepes jövedelmú országok részesedése ugyanekkor 42,0\%, az alacsony jövedelmú országoké pedig 7,2\% volt. A legtöbb szén-dioxidot (az összes kibocsátás 20,9, illetve 17,3\%-át) az Egyesült Államok és Kína produkálta. Az éves szintú kibocsátás növekedési aránya 1990 és 2004 között az Egyesült Államokban 25,5\% volt. Ezekben az években a vizsgált 177 ország közül csupán 32 csökkentette éves szén-dioxid-kibocsátását (UN Human Development Report 2007/2008, 24. táblázat).

Az EU 27 országának összesített szén-dioxid-kibocsátása 1995-ben 5214,14 milliô tonna, 2006-ban pedig 5142,80 millió tonna volt (Eurostat). Ez azt jelenti, hogy nem történt jelentôs csökkenés. 2006-ban a szén-dioxid-kibocsátás legnagyobb forrásai a közlekedési-szállítási és az energiatermelô iparágak voltak (30,9\%-os, illetve 19,3\%-os részesedéssel). Az elóbbieken belül csupán 2,6\%-ot tett ki a polgári légi közlekedésnek tulajdonítható kibocsátás, míg az országúti közlekedés és szállítás 93,1\%-ért volt felelős (uo.). A feldolgozó iparágakra és az építôiparra a teljes széndioxid-kibocsátásnak csak a $12,9 \%$-a jutott (uo.).

Az Egyesült Államokban a szén-dioxid-kibocsátás az 1990. évi 6135,24 millió tonnáról 2006-ig 7017,32 millió tonnára nőtt. A statisztikai adatok tükrében a szén-dioxid-kibocsátás legnagyobb forrásai az USA-ban is az energiatermelő, valamint a közlekedési-szállítási iparágak voltak. ${ }^{5}$ 2006-ban az összes szén-dioxid-kibocsátás 41\%-át az elektromosáram-termelés produkálta. ${ }^{6}$ Így például a Southern energiavállalat évente 172 millió tonna, az American Electric Power 169 millió tonna, a Scherer erómú pedig 25,3 millió tonna szén-dioxidot bocsátott a légkörbe (Carbon Monitoring for Action, http://carma.org, letöltve 2008. szeptember 16.). 2007-ben az USA összesen körülbelül 7 milliárd tonna szén-dioxidot produkált. Ennek a 7 milliárd tonnának körülbelül 5\%-áért a fent említett három energiatermelő vállalat (Southern, American Electric, Scherer) volt felelős.

Az energiatermelés nagy üzlet. Ez a kapitalista üzlet azonban nem tartható fenn, és éppen ez a globális felmelegedés legfốbb oka.

1. táblázat

A szállitó jármứvek caltal megtett összes út az USA-ban (millió mérföld)

\begin{tabular}{|c|c|c|c|c|c|c|c|c|c|c|}
\hline & 1960 & 1965 & 1970 & 1975 & 1980 & 1985 & 1990 & 1995 & 20000 & 2006 \\
\hline $\begin{array}{l}\text { Országúti } \\
\text { közlekededés-szállitás } \\
\text { (millió mérföld) }\end{array}$ & 718762 & 887812 & 1109724 & 1327664 & 1527295 & 1774826 & 2144362 & 2422696 & 2746925 & 2989807 \\
\hline $\begin{array}{l}\text { Repülöjáratok (millió } \\
\text { mérföld) }\end{array}$ & 858 & 1134 & 2068 & 1948 & 2523 & 3046 & 3963 & 4629 & 5664 & 6619 \\
\hline $\begin{array}{l}\text { Vasúti forgalom (mil- } \\
\text { lió mérföld) }\end{array}$ & 613 & 593 & 520 & 433 & 458 & 377 & 41.3 & 490 & 539 & 684 \\
\hline
\end{tabular}

Forrás: National Transportation Statistics 2008, 1.32 táblázat

${ }^{5}$ http://www.epa.gov/climatechange/emissions/co2_human.html (2008. szeptember 16.).

${ }^{6}$ Uo. 
2. táblázat

Teherszaillítás az USA-ban (millió hasznos tonnamérföld)

\begin{tabular}{|c|c|c|c|c|c|c|c|c|c|c|}
\hline & 1960 & 1965 & 1970 & 1975 & 1980 & 1985 & 1990 & 1995 & 2000 & 2005 \\
\hline & 5. & 3 & 709 & 3470 & 4528 & 5156 & 9064 & 12520 & 14983 & 15707 \\
\hline Ország & 000 & 359000 & 412000 & 54000 & 55000 & 610000 & 735000 & 921000 & 1074000 & \\
\hline Vasúti teherszállítás & 572309 & 697878 & 764809 & 754252 & 918958 & 876984 & 1033969 & 1305688 & 1465960 & 696 \\
\hline
\end{tabular}

Forrás: National Transportation Statistics 2008, 1.46a táblázat

Az elsố táblázat megmutatja, hogy a repülógépek, illetve országúti jármúvek által megtett összes út az USA-ban 1960 óta igen nagy mértékben növekedett, míg a vasúti szállítás volumene alig változott. A második táblázat tanúsága szerint a légi úton, országúton és vasúton szállított teheráruk összesített tömege és a jármúvek által megtett összes út hossza szintén jelentősen nốtt 1960 óta.

Hasonló trendek figyelhetók meg Európában is. Az Egyesült Királyságban például 1992-ben az országúti jármúvek által megtett összes út 424449 millió kilométer, 2003-ban pedig már 513385 millió kilométer volt (Eurostat). Németországban ugyanez az adat az 1988. évi 459671 millió kilométerról 1995-ig 603516 millió kilométerre emelkedett. Az EU 15 országában az országúti teherszállítás összesített volumene 1999-ben 1211281 millió tonnakilométer, 2005-ben pedig 1479820 millió tonnakilométer volt.

3. táblázat

$A$ világ legnyereségesebb vállalatai 2008-ban

\begin{tabular}{|l|l|l|c|}
\hline \multicolumn{1}{|c|}{ Rangsor } & \multicolumn{1}{|c|}{ Vállalat } & \multicolumn{1}{|c|}{ Iparág } & $\begin{array}{c}\text { Profit 2007 (milliárd USA- } \\
\text { dollár) }\end{array}$ \\
\hline 1. & ExxonMobil & olaj és gáz & 40,61 \\
\hline 2. & Royal Dutch Shell & olaj ćs gáz & 31,33 \\
\hline 3. & Gazprom & olaj és gáz & 23,30 \\
\hline 4. & General Electric & vegyes & 22,21 \\
\hline 5. & BP & olaj és gáz & 20,60 \\
\hline 6. & Total & olaj és gáz & 19,24 \\
\hline 7. & HSBC Holdings & bankszektor & 19,13 \\
\hline 8. & Chevron & olaj és gáz & 18,69 \\
\hline 9. & PetroChina & olaj és gáz & 18,21 \\
\hline 10. & Microsoft & szoftver és szolgáltatások & 16,96 \\
\hline
\end{tabular}

Forrás: A Forbes 2000 listája a világ legnagyobb vállalatairól, 2008

2008-ban a világ tíz legnyereségesebb nagyvállalata közül nyolc olajvállalat volt, lásd 3. táblázat. Ezek összesített nyeresége 2007-ben 172 milliárd USA-dollárra rúgott. Ez is jelzi az okokat, amelyek következtében folytatódik a környezetet veszélyeztetố szén-dioxid-kibocsátás, emelkednek az olajárak, és továbbra is hiány van megújuló forrásokban, mivel a fosszilis tüzelőanyagok kitermelése és feldolgozása a legnyereségesebb üzlet, s a kapitalista nagyvállalatok az emberi és környezeti érdekek fölébe helyezik a pénzbeli nyereséget. 
A statisztikai adatok szerint az, amit egyesek posztindusztriális társadalomnak (Bell 1976), tudástársadalomnak (Stehr 2002), információs társadalomnak (Porat 1978) vagy hálózati társadalomnak (Castells 1996) neveznek, nem hozott magával olyan immateriális termelési kultúrát, ami nem járna együtt többé veszélyes, a környezetet károsító anyagok kibocsátásával. A fosszilis tüzelốanyagokra alapozott energiatermelés nagy üzlet. A nyersolajalapú üzemanyagok felhasználására épülő közlekedés és a kereskedelmi teherszállítás volumene folyamatosan növekszik. Az internet közvetítésével folyó kommunikáció kibóvülése az 1990-es évek óta nem hozta magával a közlekedési és szállítási igények csökkenését, hanem - úgy túnik - inkább még hozzá is járult a teherszállítás és az egyéni utazások mennyiségének növekedéséhez. A világ energiaellátása igen nagy mértékben az olajra és a szénre épül. Még a háborúk is (például Irakban) azt a célt szolgálják, hogy biztosítva legyen a nyugati érdekeltségek hozzáférése a nyersolajforrásokhoz (Harvey 2003; Wood 2003). A szén-dioxid-kibocsátás legfóbb forrása az ásványi eredetû üzemanyagok elégetése, ami elóidézi a globális felmelegedést. Mivel a globális társadalom egyre inkább az ásványi tüzelő́anyagokból nyert energiára és az ásványi eredetú üzemanyagokat fogyasztó, növekvố mennyiségú szállításra támaszkodik, ez a társadalom nem nevezhetô ökológiailag fenntartható társadalomnak, s az utóbbi ötven év során valójában ökológiailag egyre kevésbé fenntartható társadalommá vált. Ennek a helyzetnek a megváltozására valószínúleg nem számíthatunk mindaddig, amíg az ásványi üzemanyagok nagy üzletet jelentenek. Az információs társadalom kialakulása nem járt együtt ökológiailag fenntartható társadalom létrejöttével. Az információs társadalom ökológiailag nem fenntartható társadalom.

\subsection{A társadalmi-gazdasági rendszer állapota}

A Microsoft korábbi elnök-vezérigazgatója és a vállalat egyik fốrészvényese, Bill Gates vagyona a Forbes magazin által a világ leggazdagabb milliárdosairól vezetett lista szerint 2008-ban körülbelül 58 milliárd USD volt. Ha feltételezzük, hogy Gates ezt a vagyont húszéves korában, 1975-ben kezdte felhalmozni, akkor az évi átlagos jövedelme 1,8 milliárd dollár, átlagos havi jövedelme pedig körülbelül 150 millió dollár lehet. Feltételezve továbbá, hogy igen intenzíven dolgozik, ez havonta 320 munkaórát számítva 470 ezer dolláros órabért jelenthet. 2006-ban az egy lakosra jutó átlagos évi jövedelem az USA-ban 26036 dollár volt, ami 2170 dolláros havi jövedelemnek felel meg. ${ }^{7}$ Bill Gates átlagos havi jövedelme tehát 69 124-szerese az átlagos amerikai dolgozók jövedelmének. Ebból két kérdés adódik: Bill Gates vajon 69 000-szer annyi órát dolgozik, mint a közönséges emberek? Ô vajon 69 000-szer annyira fontos a társadalom számára, mint azok az emberek, akik például sampont, oldószereket, szappant, vécépapírt, könyveket stb. gyártanak, csomagolnak vagy értékesítenek? Nem. A válasz az, hogy a jövedelem nem a teljesítménytól, hanem örökölt vagy szerzett előjogoktól, mások kizsákmányolásától és a szerencsétól függ. Ezzel a példával mindössze arra igyekeztünk rámutatni, hogy a gazdagok azért gazdagok, mert mások szegények, a társadalmi osztályhoz való tartozás pedig a tulajdonosok és a nem tulajdonosok, a gazdagok és a nem gazdagok közötti viszony kifejezôdése.

\footnotetext{
${ }^{7}$ Forrás: Current Population Survey, Bureau of Labour Statistics and Census Bureau, http://pubdb3 census.gov/macro/032007/hhinc/new02_001.htm. (letöltve: 2008. szeptember 15.).
} 
4. táblázat

A világ legnyereségesebb nagyvállalatai a média, az IKT és a kultúra terïletén

\begin{tabular}{|c|l|l|l|r|}
\hline $\begin{array}{c}\text { Rang- } \\
\text { sor }\end{array}$ & \multicolumn{1}{|c|}{ Vállalat } & \multicolumn{1}{|c|}{ Ország } & \multicolumn{1}{c|}{$\begin{array}{c}\text { Profit, } 2007 \\
\text { (milliárd USA- } \\
\text { dollár) }\end{array}$} \\
\hline 1. & Microsoft & USA & szoftver & 16,96 \\
\hline 2. & Telefónica & Spanyolország & telekommunikáció & 13,00 \\
\hline 3. & AT\&T & USA & telekommunikáció & 11,95 \\
\hline 4. & Nokia & Finnország & technológiai hardver és berendezés & 10,52 \\
\hline 5. & IBM & USA & szoftver és szolgáltatások & 10,42 \\
\hline 6. & France Telecom & Franciaország & telekommunikáció & 9,20 \\
\hline 7. & Samsung Electronics & Dél-Korea & félvezetók & 8,56 \\
\hline 8. & China Mobile & Kína & telekommunikáció & 8,29 \\
\hline 9. & Cisco Systems & USA & technológiai hardver és berendezés & 8,07 \\
\hline 10. & Hewlett-Packard & USA & technológiai hardver és berendezés & 7,85 \\
\hline & & & Összesen: & 104,82 \\
\hline
\end{tabular}

Forrás: Forbes, 2000, 2008.

5. táblázat

A világ 5 legkevésbé fejlett országának GDP-je

\begin{tabular}{|c|l|c|}
\hline HDI-Rangsor & \multicolumn{1}{|c|}{ Ország } & GDP (milliárd USD), PPP \\
\hline 177. & Sierra Leone & 4,5 \\
\hline 176. & Burkina Faso & 16,0 \\
\hline 175. & Bissau-Guinea & 1,3 \\
\hline 174. & Niger & 10,9 \\
\hline 173. & Mali & 14,0 \\
\hline & Összesen: & 46,7 milliárd USD \\
\hline
\end{tabular}

Forrís: UN Human Development Report 2008

A 4. és az 5. táblázat adatai azt mutatják, hogy a világ legnyereségesebb tudásalapú nagyvállalatainak éves profitja 2,2-szeresen meghaladja az öt legkevésbé fejlett ország összesített nemzeti jövedelmét. Ezt a tíz nagyvállalatot néhány ezer részvényes tartja ellenórzése alatt, míg a szóban forgó öt ország lakossága majdnem ötven millió foót tesz ki.

6. táblázat

A vilíg legnagyobb állótókevagyonnal rendelkezó nagyvállalatai

\begin{tabular}{|c|l|l|l|c|}
\hline Rangsor & \multicolumn{1}{|c|}{ Vállalat } & \multicolumn{1}{|c|}{ Ország } & \multicolumn{1}{c|}{ Iparág } & $\begin{array}{c}\text { Tókevagyon, 2008 } \\
\text { (milliárd USD) }\end{array}$ \\
\hline 1. & AT\&T & USA & telekommunikáció & 275,64 \\
\hline 2. & Vodafone & Egyesült Királyság & telekommunikáció & 214,97 \\
\hline 3. & Verizone Communications & USA & telekommunikáció & 186,96 \\
\hline
\end{tabular}

Forrás: Forbes, 2000, 2008. 
Az alacsony jövedelmú országok összesített külsố adósságállománya 2007-ben 400,7 milliárd USD volt (World Development Index 2007), míg a két legnagyobb tudásalapú vállalat (AT\&T, Vodafone) állótókéjének értéke együttesen 490,61 milliárd USD-nek felelt meg (lásd 6. táblázat). Az ATÆT tókevagyona (275,64 milliárd USD) önmagában is 2,2-szeresen meghaladta a 22 legkevésbé fejlett ország összes külsó adósságállományát (126,2 milliárd USD) (WDI 2007).

Ezek az adatok azt mutatják, hogy a tudásalapú nagyvállalatok részét képezik a társadalmi-gazdasági egyenlő́tlenség globális problémájának. A Branco Milanovic (2007a, b) által kalkulált adatok szerint a globális jövedelmi egyenlốtlenség mértéke az 1988 és 2003 közötti években 0,62-ról 0,70-ra nôtt. ${ }^{8}$ Az adatok szerint a „,hálózati” vagy „információs” társadalom kialakulása nem hozta magával a disztributív társadalmi-gazdasági egyenlő́tlenség csökkenését, és ennélfogva a társadalmi-gazdasági dimenzióban nem tekinthetố fenntarthatónak.

1989 és 1993 között az 4. sz. lábjegyzetben felsorolt 28 fejlett ország teljes lakosságának 57,8\%-a $(\mathrm{N}=40209)$ nem táplált bizalmat a nagyvállalatok iránt. Ez az arány az 1999 és 2004 közötti idốszakban 59,9\%-ra ( $\mathrm{N}=17$ 192) növekedett.

\subsection{A politikai rendszer állapota}

7. táblázat

Politikai attitüdök 28 fejlett országban

\begin{tabular}{|l|c|c|}
\hline \multicolumn{1}{|c|}{ Indikátor } & $1989-1993$ & $1999-2004$ \\
\hline $\begin{array}{l}\text { A bizalom hiánya vagy csekély bizalom a parlament } \\
\text { iránt }\end{array}$ & $57,9 \%(\mathrm{~N}=37717)$ & $63,3 \%(\mathrm{~N}=34856)$ \\
\hline $\begin{array}{l}\text { A bizalom hiánya vagy csekély bizalom a politikai } \\
\text { pártok iránt }\end{array}$ & $47,9 \%(\mathrm{~N}=2656)$ & $77,3 \%(\mathrm{~N}=5414)$ \\
\hline $\begin{array}{l}\text { A bizalom hiánya vagy csekély bizalom a kormány- } \\
\text { zat iránt }\end{array}$ & $64,4 \%(\mathrm{~N}=2784)$ & Átlag: 4,99 ( $\mathrm{N}=30898)$ \\
\hline $\begin{array}{l}\text { A politikai rendszernek adott ,osztályzat” } \\
(1=\text { rossz, 10 = nagyon jó) }\end{array}$ & & $47,8 \%(\mathrm{~N}=34386)$ \\
\hline $\begin{array}{l}\text { Egyáltalán nem vagy nem nagyon elégedett azzal, } \\
\text { ahogyan a demokratikus rendszer fejlốdik }\end{array}$ & $48,4 \%(\mathrm{~N}=41016)$ & $52,7 \%(\mathrm{~N}=26532)$ \\
\hline $\begin{array}{l}\text { Egyáltalán nem vagy nem nagyon érdeklốdik a } \\
\text { politika iránt }\end{array}$ & $45,5 \%(\mathrm{~N}=37813)$ & \\
\hline $\begin{array}{l}\text { Teljesen egyetért azzal, hogy a kormányzást sokkal } \\
\text { nyitottabbá kellene tenni a lakosság előtt }\end{array}$ & & \\
\hline
\end{tabular}

Forrís: World Values Survey (az országok jegyzékét lásd az 1. lábjegyzetben)

A 7. táblázat 28 olyan fejlett országra nézve tükrözi a lakosság politikai attitúdjét, amelyekben a két felmérési időszakban liberális-demokratikus képviseleti politikai rendszer állt fenn. A két időszak között eltelt tíz év során ment végbe valamennyi országban az internet elterjedése, valamint az e-kormányzati szolgáltatások és az online politikai kommunikáció egyre fokozódó térnyerése. Mindazonáltal az adatok tanúsága

${ }^{8}$ A szerzố itt feltehetôen az ún. Gini-indexet használja az egyenlôtlenség mértékének kifejezésére. A Giniindex értéke 0 és 1 (vagy $0 \%$ és 100\%) között változhat: a 0 érték a teljes egyenlôséget, az 1 érték pedig a maximális egyenlőtlenséget jelzi. - A ford. 
szerint a politikai rendszerrel kapcsolatban jelentôs bizalomhiány és magas arányú elégedetlenség nyilvánult meg. Az a három változó, amelyek lehetốvé teszik a két vizsgált idôszak közvetlen összehasonlítását (a parlament és a politikai pártok iránti bizalom, valamint a politikai érdeklôdés) az állampolgárok növekvố politikai elégedetlenségét mutatja. Az olyan politikai rendszerek, amelyekben az állampolgároknak több mint a fele nyilvánvalóan elégedetlen, nem tekinthetók politikailag fenntarthatónak. Az e-kormányzati szolgáltatások kialakulása nem járult hozzá nagyobb arányú politikai bizalom, elégedettség és érdeklődés kifejlődéséhez. Az e-kormányzat a lakosságot önmagától elidegenítő politikai rendszer részévé vált.

\subsection{A kulturális rendszer állapota}

1992-tól 2006-ig az OECD-országokban a felsőfokú végzettségú állampolgárok átlagos aránya a 25-64 éves korosztályban 19\%-ról 27\%-ra emelkedett (OECD Education at a Glance Statistics). Az egyes országok között azonban óriási különbségek mutatkoznak. A vezető OECD-országok ebben a tekintetben Kanada (47\%) és Japán (40\%), míg az országok jelentôs részére jóval alacsonyabb (20\%-nál kisebb) arányok jellemzók (Ausztria: 18\%, Magyarország: 18\%, Mexikó: 15\%, Cseh Köztársaság: 14\%, Szlovák Köztársaság: 14\%, Olaszország: 13\%, Portugália: 13\%, Törökország: 10\%). Ez a mutató ugyanakkor igen magas értékú az OECD számos partnerországában: Oroszországban 54\%, Izraelben pedig $46 \%$. A felsőoktatás - mivel a társadalomnak éppen azt az alrendszerét alkotja, ahol az emberek megtanulják a tudás szisztematikus megszerzését, alkalmazását és újratermelését - központi fontosságú a tudástársadalmakban. A számos „fejlett” országban mért alacsony felsőoktatási részvételi arányok azt mutatják, hogy a tudástársadalom irányában megtett fejlődés szempontjából, vagyis a tudás tekintetében sok gazdasági értelemben fejlettnek tekintett ország inkább „fejlôdó” országnak számít. 2008-ban Észak-Amerikában és Nyugat-Európában a felsôoktatási intézményekbe beiratkozott hallgatók aránya (a középfokú iskolai oktatásból három évvel korábban kikerült tanulók létszámához viszonyító GER-mutatószámmal mérve) a Luxemburgban regisztrált 12\%-os és a Finnországban kimutatott 92\%-os szint között mozgott, és ezeknek az országoknak a legtöbbjében 50\% fölött volt (UNESCO EFA Global Monitoring Report 2008, 9A táblázat). Ehhez képest a Szaharától délre fekvő 32 ország közül 24-ben, amelyekról adatok állnak rendelkezésre, a GER értéke 5\% alatt maradt (például Malawi: 0,4\%, Angola: 0,8\%, Csád, Eritrea, Gambia, Mozambik, Niger és Tanzánia: 1\%) (uo.). A 2008. évben a GER átlagos értéke a fejlődó országokban 17\%, a fejlett országokban pedig $66 \%$ volt. Ez azt mutatja, hogy a tudástársadalmak kialakulása felé eddig megtett haladás globálisan igen egyenlótlenül oszlik meg.

A felmérési adatok tanúsága szerint (World Values.Survey) 1989 és 1993 között 22 fejlett ország (lásd 4. lábjegyzet) teljes lakosságának 59,8\%-ára $(\mathrm{N}=40929)$ a sajtó iránti bizalom hiánya vagy csekély mértéke volt jellemzó, s ez az adat az 59,7\%-os értéken állandó maradt az 1999 és 2004 közötti években is $(\mathrm{N}=33488)$.

Ha az oktatást a kulturális rendszer fontos összetevójének tekintjük, akkor ezek az adatok azt bizonyítják, hogy a jelenlegi globális tudástársadalom nem tekinthetô fenntarthatónak, mivel a felsốoktatásban részt vevốk aránya egyenlótlen megoszlást mutat, és sok országban igen alacsony a felsőfokú végzettségúek aránya. 


\subsection{Fenntartható-e az információs társadalom?}

A fentiekben áttekintettük a fenntarthatóság néhány indikátorát (ökológiai indikátorok: a környezetszennyezés csökkentésének igénye, az ásványi tüzelőanyagokból nyert energia részesedése a teljes energiaellátásból, az évenkénti szén-dioxid-kibocsátás, a légi és országúti közlekedésben megtett utak évi összesített értéke, a légi és országúti teherszállítás éves volumene; társadalmi-gazdasági indikátorok: jövedelmi egyenlőtlenség, nagyvállalatok iránti bizalom; politikai indikátorok: a liberális demokrácia intézményei, köztük a parlament, a politikai pártok és a kormányzat iránti bizalom; a liberális politikai rendszernek adott „osztályzat”, elégedettség a liberális demokratikus rendszerrel, politikai érdeklődés, a kormányzat lakosság elốtti nyitottságának, átláthatóságának hiánya; kulturális indikátorok: felsófokú végzettségú állampolgárok aránya, a felsốoktatási intézményekbe való beiratkozási arányok, a sajtó iránti bizalom).

A felsoroltakhoz még sok más indikátort is hozzá lehetne tenni (vö. Fuchs 2006e), de az induktív falszifikáció módszerével elvethetố az a hipotézis, miszerint az információs társadalom fenntartható lenne, illetve az elmúlt évtizedekben közelebb került volna a fenntarthatósághoz. Az adatok azt mutatják, hogy az ökológiai válság, a jövedelmi egyenlootlenség, valamint a liberális demokráciával és annak intézményeivel való elégedetlenség az elmúlt évtized során növekedett, és a világ sok részén jelenleg alacsony arányú a felsốoktatásban való részvétel. Ennélfogva el kell fogadnunk azt a következtetést, hogy a globális információs társadalom az ökológiai, a társadalmi-gazdasági, a politikai és a kulturális dimenziók tekintetében egyaránt fenntarthatatlan. Problematikus tehát információs társadalomról, hálózati társadalomról vagy tudástársadalomról beszélnünk, mivel ezek olyan pozitív konnotációkkal bíró kifejezések, amelyek elkendőzik, hogy a jelenlegi társadalom mindenekelő́tt globális problémákkal és erôs rétegezettséggel terhelt társadalom. A nagyvállalatok és a gazdagok a bizonytalan egzisztenciájú tömegek kárára növelik vagyonukat, a liberális politikai rendszerekben olyan politikai elitek játszanak domináns szerepet, amelyektól sok ember elidegenedett, és a lakosság jelentôs része nem érzi magát megfelelốen képviseltnek, miközben a rendszerezett tudás előállítását és közvetítését az oktatás és a sajtó alrendszerében egy kulturális elit tartja ellenőrzése alatt. Úgy túnik, hogy az ökológiai problémákat, köztük a globális felmelegedést nagyrészt a gazdasági elit hathatósan érvényesített érdekei okozzák. Tekintettel a jelenkori társadalom ilyen rétegezett jellegére, az „információs társadalom” helyett szívesebben használom a „transznacionális információs kapitalizmus” kifejezést (Fuchs 2008a). A társadalom transznacionálissá válása azt jelzi, hogy a gazdasági, politikai és kulturális folyamatok egyre inkább áthatolnak a nemzeti határokon, az „információs” kifejezés pedig arra utal, hogy a tudás és az információs technológiák alakítják a termelés, a döntéshozatal és a mindennapi élet folyamatait. Az információs jelleg formailag érvényre jut a társadalomépítő folyamatok szervezôdésében, de nem képvisel olyan minôséget, ami egy új társadalom kialakulását eredményezte volna. A kapitalizmus ebben a meghatározásban annyit jelent, hogy a gazdasági, politikai és kulturális hatalom forrásai (a pénz, az erô és az értékeket meghatározó befolyás) a globális társadalom igen nagy részeinek kárára halmozódik fel az elitek kezében, és a felhalmozásnak ez a logikája máris komoly ökológiai problémákat eredményezett. 


\section{Irodalom}

Althusser, Louis 1971/1994: Ideology and ideological state apparatuses. In Žižek, Slavoj (ed.): Mapping ideology. London, Verso, 100-140.

Beck, Ulrich 1992: Modern society as a risk society. In Stehr, Nico - Ericson, Richard

V. (eds.): The culture and power of knowledge. Berlin, De Gruyter, 199-214.

Bell, Daniel 1976: The coming of post-industrial society. New York, Basic Books.

Castells, Manuel 1996: The rise of the network society. Malden, MA, Blackwell.

Fuchs, Christian 2006e: Towards a global sustainable information society (GSIS)? TripleC, Vol. 4, No. 1, 40-99, http://triple-c.at/index.php/tripleC/article/view/25 (accessed on September 16, 2008).

Fuchs, Christian 2008a: Internet and society: social theory in the information age. New York, Routledge.

Gramsci, Antonio 1971: Selections from the prison notebooks. New York, International Publishers.

Horkheimer, Max - Adorno, Theodor W. 1944/2002: Dialectic of enlightenment. New York, Seabury.

Lukács, Georg 1923/1972: History and class consciousness. Cambridge, MA, MIT Press.

Macpherson, Crawford Brough 1973: Democratic theory. Oxford, Oxford University Press.

Marcuse, Herbert 1964: One-dimensional man. New York, Routledge.

Marx, Karl - Engels, Friedrich (MEW) Werke. Berlin, Dietz.

Milanovic, Branko 2007a: An even higher global inequality than previously thought: a note on global inequality calculations using the 2005 ICP results. http://ssrn.com/ abstract $=1081970$ (Accessed on May 22, 2008).

Milanovic, Branko 2007b: Globalization and inequality. In Held, David - Kaya, Ayse (eds.): Global inequalities. Cambridge, Polity, 26-49.

Porat, Marc 1978: Global implications of information society. Journal of Communication, Vol. 28, No. 1, 70-80.

Serageldin, Ismail 1995: The Human Face of the Urban Environment. In Serageldin, Ismail et al. (eds.): Proceedings of the Second Annual World Bank Conference on Environmentally

Sustainable Development: The Human Face of the Urban Environment. Washington, D. C., September 19-21, 1994. Washington, D. C., World Bank, 16-20.

Stehr, Nico 2002: Knowledge and economic conduct. Toronto, Toronto University Press.

World Commission on Environment and Development (WCED) 1987. Our Common Future. Oxford, Oxford University Press.

Wood, Ellen Meiksins 2003: Empire of Capital. London, Verso.

Žižek, Slavoj (ed.) 1994: Mapping ideology. London, Verso. 